\title{
Radiological characteristics of screen-detected lung cancers: predictive for histological subtype?
}

\author{
MA Heuvelmans ${ }^{1 *}$, E Salters ${ }^{1}$, HJM Groen ${ }^{2}$, P De Jong ${ }^{3}$, WPTM Mali ${ }^{3}$, M Oudkerk ${ }^{1}$, R Vliegenthart ${ }^{1}$ \\ From International Cancer Imaging Society (ICIS) 14th Annual Teaching Course \\ Heidelberg, Germany. 9-11 October 2014
}

\begin{abstract}
Aim
To evaluate CT-morphological features of lung cancers detected in a CT lung cancer screening trial, and to determine the correlation between CT-morphological features and the histopathological diagnosis of screen-detected cancers.
\end{abstract}

\section{Methods}

197 solid lung cancers (192 participants) detected in all four screening rounds of the Dutch-Belgian randomized lung cancer screening trial (NELSON) were included. CTmorphological features included nodule shape, margin, location, volume, and volume-doubling time (VDT). Based on histopathology, cancers were divided into four groups: adenocarcinoma $(\mathrm{N}=114)$, squamous cell carcinoma $(\mathrm{N}=37)$, large cell carcinoma $(\mathrm{N}=28)$ and neuro-endocrine cancers $(\mathrm{N}=18)$. Data were analyzed using ANOVA, Chi-square and Fischer's exact test.

\section{Results}

Mean participant age was 61.3 years (95\%-confidence interval [CI]: 60.5-62.2), and 160/192 (83.3\%) were male. In all four histopathologic groups, the majority of cancers had a spherical nodule shape (70.6-95.8\%). Margins of malignant nodules were most often lobulated (39.3-45.9\%) and spiculated (22.2-35.7\%), without statistically significant difference between histopathological groups. Most cancers (63.5\%) were located in the upper lobes, adenocarcinomas significantly more often $(71,1 \%)$ than other types of cancers $(\mathrm{p}=0.004)$. Adenocarcinomas had a higher mean VDT than large cell carcinomas (214.8 days, 95\%-CI: 186.2243.4 days vs 96.8 days, $95 \%$-CI: $15.8-177.9$ days $[\mathrm{p}<0.05]$ ).

\footnotetext{
${ }^{1}$ Center for Medical Imaging - North East Netherlands, Department of Radiology, University of Groningen, University Medical Center Groningen, Groningen, Netherlands

Full list of author information is available at the end of the article
}

VDTs of other histopathological subgroups did not differ significantly.

\section{Conclusion}

Only VDT and location in the upper versus lower lobes are associated with histopathological diagnosis of screen-detected lung cancers. No discrimination can be made between different histopathologic cancer types based on CT-morphological features alone.

\section{Authors' details}

${ }^{1}$ Center for Medical Imaging - North East Netherlands, Department of Radiology, University of Groningen, University Medical Center Groningen, Groningen, Netherlands. ${ }^{2}$ Department of Pulmonology, University of Groningen, University Medical Center Groningen, Groningen, Netherlands. ${ }^{3}$ Department of Radiology, University Medical Center Utrecht, Utrecht, Netherlands.

Published: 9 October 2014

doi:10.1186/1470-7330-14-S1-P20

Cite this article as: Heuvelmans et al:: Radiological characteristics of screen-detected lung cancers: predictive for histological subtype? Cancer Imaging 2014 14(Suppl 1):P20.

Submit your next manuscript to BioMed Central and take full advantage of:

- Convenient online submission

- Thorough peer review

- No space constraints or color figure charges

- Immediate publication on acceptance

- Inclusion in PubMed, CAS, Scopus and Google Scholar

- Research which is freely available for redistribution

Submit your manuscript at www.biomedcentral.com/submit
() Biomed Central 